for a moment be questioned; it means much more than that we shall be able to telephone to America; it means that we shall be able to telegraph at the speed of the automatic transmitter. The present speed of Transatlantic telegraphy is something like 20 words a minute, and there are 12 duplexed cables having, therefore, a carrying capacity of about 500 words a minute. A single distortionless cable, built on Dr. Pupin's plan and working with an automatic transmitter, would have, therefore, a carrying capacity equal to that of all the existing cables.

\section{INDIGO AND SUGAR.}

THE Behar Sugar Commission, which was appointed in October of last year to see whether improvements might not be made in the cultivation and manufacture of cane sugar, has completed its task. The report has been issued with commendable promptitude-scarcely five months having elapsed from the appointment of the Commission to the presentation of its report. The Commission was primarily appointed because of the perilous position of the indigo industry, to see whether it might not be possible to grow the sugar cane and indigo crops in rotation.

The Times of April I 5 contains an article upon this report. One thing the Commission seems to have made clear is that the methods employed in the sugar industry have been on the same happy-go-lucky slip-shod fashion as those until lately used in the manufacture of natural indigo. The yield of sugar per acre in India averages about one ton, whereas in Barbadoes it is three tons, and four tons are obtained in Java.

The Indian Government, taking alarm at the great increase in the imports of beet sugar and wishing to aid the indigenous planter, inposed countervailing duties in March I899. The duties have apparently failed in their object, as the imports of beet sugar for 1900 were greater than for I898. It would appear that very little attempt has been made in India "to treat the soil or plant the canes on scientific principles," and that the methods of refining the sugar are rough, crude and wasteful, so that under such conditions the yield of the finished article is not what it should be, and the quality is poor; Indian sugar is, therefore, unable to compete with sugar refined by modern scientific methods and appliances.

It is further stated that there is an increasing tendency in India to prefer sugar which has been refined to unrefined sugar. The Commission recommend the employment of modern and up-to-date apparatus. We are glad to note that they do not recommend indiscriminate help to the individual planter or refiner, but suggest that such assistance as is desirable should be given in helping systematic experiments at a central station.

Turning now to the indigo industry, which was the primary cause of the appointment of the Commission, we find that the indigo planter, now thoroughly alive to the danger which threatens him, is exerting himself to improve the yield of indigo. In the first place, by the employment of artificial manures, principally superphosphates, an increased plant production of from 50 to 100 per cent. has been obtained. In manufacturing indigo, it will be remembered (NATURE, November I) that it is usual, when the plant has reached maturity, to cut it near to the ground and to steep the whole plant. After a few months the fresh shoots which have sprung up are again cut, but the yield of indigo from this second crop is inferior to that obtained from the first. It has been suggested, seeing that almost the whole of the colouring matter is contained in the leaves, that the plant should not be cut down, but that the leaves only should be stripped off and steeped. It is calculated that four or five strippings could be obtained during the manufacturing NO. I 644, VOL. 64$]$ season, and thus a very much larger quantity of indigo would be produced than by the methods at present in vogue.

The old beating process for oxidising the liquors obtained after the plant has been steeped is gradually being replaced by the use of the "blower." In this method air is blown through a number of perforated pipes which are placed at the bottom of the vats, with the result that oxidation is more rapid and complete, and about 25 to 30 per cent. more colouring matter is produced than by the old process. Mr. Rawson, in addressing a meeting of those interested in the indigo industry at Calcutta on February 20, said that the output of indigo in North Behar last year amounted to about 60,000 maunds, ${ }^{1}$ and that at least 12,000 maunds more would have been produced had the new "blowing" process been employed.

A manufacturing industry, such as that of indigo, which is to a large extent dependent upon atmospheric conditions, has naturally seen many dark days. But when the supply has been short there has generally been an enhancement in prices. The Commission is of opinion that a rise of price owing to bad seasons or short supplies can no longer be looked for, and say in their report : "It is reasonable to anticipate that the competition of synthetic indigo will prevent any future increase in the price of vegetable indigo, that it will soonest and most injuriously affect the finest and most expensive indigo, which is that of Behar, and cause a further reduction in price, which would hardly clear the planter in a good season, while a bad season would be ruinous to him." They go on to say, "it is obviously expedient that indigo planters should possess in sugar and other products resources which, if they are carefully and intelligently utilised, will enable them to contemplate the future of indigo with equanimity."

In order to aid the Indian indigo industry, the Bengal Government has formally agreed to grant an annual subsidy of 50,000 rupees for three years for further chemical and scientific researches with regard to indigo cultivation.

Indigo planters claim that at present the natural dye can be placed on the market at prices which can undersell the synthetic product. This is good news, but it is difficult to see how it is in the long run to hold its own against the artificial product, which is of uniform quality, requires no grinding, and is unaffected by vicissitudes of weather.

Prof. Armstrong, in a long letter to the Times, says that "The truly serious side of the matter, however, is not the prospective loss of the entire indigo industry so much as the fact that an achievement such as that of the Badische Company seems to be past praying for here."

Whether or not the natural indigo industry is to become a thing of the past remains to be seen, but if the replacement of natural indigo by a synthetic article produced in Germany leads British manufacturers to realise more fully the importance of trained scientific assistance, the decline, although in itself a great calamity, might not be entirely without its compensations.

Since writing the above, I have received a copy of an address upon "The Synthesis of Indigo," delivered by Prof. Meldola before the Society of Arts on April 17. In introducing the subject Prof. Meldola says that it is now often considered unpatriotic to "call public attention to any branch of industry in which we are being beaten by foreign competitors." He, however, considers that "The real enemies of British industry are those who, by virtue of their positions as politicians, economists, or as men of science, try to blind the public and to allure the manufacturer and merchant into a fool's paradise of false security."

1 The Bengal factory maund is $74^{\circ} 66 \mathrm{lbs}$. 
Then follows a very lucid and interesting historical survey of the chemistry of synthetic indigo. Attention is called to the fact that the first patent bears the date of March 19, 1880, and that although we knew that artificial indigo prepared by this, the cinnamic acid synthesis, could not compete with the natural product, yet its appearance caused much consternation among indigo planters. But because the threatened storm did not break, the planters evidently quickly forgot their fright and returned complacently to their old rule-of-thumb methods. Not so the chemists ; they steadily and perseveringly plodded on, and in 1882 von Baeyer and Drewson brought out another synthesis, viz. the condensation of acetone and orthonitrobenzaldehyde in presence of caustic alkali. This process, or a modification of it, is employed at the present by the firm of Messrs. Meister Lucius and Brunning; but as the supply of the raw material - toluene-is limited, Prof. Meldola, speaking as an individual, says: "Were I a planter, I should have no anxiety whatever with respect to a competing product which starts from toluene." Every Iooo gallons of coal tar yields about $6 \frac{3}{4}$ gallons of benzene and $3 \frac{1}{4}$ gallons of toluene, therefore any process which started with benzene as the out-going product should be better able to compete than one in which toluene is the starting material. However, although there are several syntheses which start from aniline (produced from benzene), the methods employed are so costly that at present the planter has very little to fear in this direction.

Naturally the chief portion of the paper is devoted to Heumann's synthesis, as at present worked by the Badische Company. This process, which starts from naphthalene, the supplies of which are practically unlimited, was described in NATURE, November 29.

In his references to the Badische Company Prof Meldola quoted the following facts from the official report prepared for the Paris Exhibition:-

"The factory at Ludwigshafen employs 148 scientific chemists, 75 engineers and technical experts, and 305 members of the mercantile staff. In 1865 they commenced with 30 workmen, and they now employ over 6000 . The consumption of coal is about 243,000 tons per annum ; water is supplied to the factory to the extent of some $20,000,000$ cubic metres annually; they make $12,000,000$ kilogrammes of ice, and over I2,000,000 cubic metres of coal gas in the course of the year. The electric installation consists of eight dynamos, the currents from which serve for illumination, motive power and electrolytic processes. Steam is supplied from 102 boilers, which serves for heating purposes and for driving 253 steam engines."

Let the British manufacturer and the Indian indigo planter try to digest these hard facts and figures. wonder whether there are 148 scientific chemists employed by manufacturers in the whole of the United Kingdom. Let them also remember that these figures only refer to one firm.

Finally, Prof. Meldola refers to the natural product versus synthetical indigo. $\mathrm{He}$ is unable to hold out the hope that the natural article will in the long run be able to compete with the product of the German factory. "The planters have allowed twenty years of activity on the part of the chemists to pass by with apathy and indifference, and at the last moment only have they called in expert assistance."

It is truly marvellous that only the British planter should have been so lethargic. In Java the Dutch planters "have had the wisdom to avail themselves of the resources of the botanical gardens for experimental purposes, and their chemists and bacteriologists working in Holland in co-operation with the planters have, as is well known, for many years past been contributing to chemical literature the results of their investigations."

Reference is made to the contradictory opinions as to NO. I644, VOL. 64] what goes on in the steeping vats, as to whether the resolution of the glucoside indican into indigotin is due to bacterial fermentation, or whether it is one of ordinary zymolysis. Attention is also directed to the drying process, which often extends over several weeks, and during which time it is stated that a fungus grows on the cakes and ammonia is evolved. Prof. Meldola asks whether this may not be due to the destruction of indigo by a micro-organism. I have myself often wondered that in all the suggestions for improving the yield and quality of indigo no one appears to have drawn attention to this apparent decomposition. It seems possible that more thorough washing and rapid drying in a current of hot air would perhaps prevent this. In his closing remarks Prof. Meldola refers to the antiquity of the industry, and questions whether the methods at present employed in India are very different to those used in the time of the Pharaohs.

F. MOLLWO PERKIN.

\section{THE OLDER CIVILISA TION OF GREECE.}

\section{THE sixth volume of the Annual of the British School} at Athens contains matter of extraordinary interest to students of the history, not only of Greece, of Egypt and Western Asia, but also of mankind in general. The culture which now dominates the world is the child of the civilisation of Ancient Greece, and any archæological discovery which tends to increase our knowledge of the beginnings of Greek civilisation possesses an importance and an interest far greater than that of any other possible discovery whatever in the archæological field.

For the last twenty years, since Schliemann first unveiled the treasures of the citadel of Mycenæ, it has been recognised that the culture of classical Greece as we know it is but the second epoch of Greek civilisation. Classical Greece had a past the true history of which had been half forgotten, had been preserved in confused and contradictory legends. The culture of the past had bloomed from end to end of the Greek world, in cities, some like Athens or Knôssos, of renown in classical as well as præ-classical days, others like Mycenæ and Tiryns, cities whose fame ceased to be when the Dorians entered Greece. This culture was bronze-using, and was, in fact, the Greek phase of the European culture of the Bronze Age, a phase earlier in date than the phases of Central and Northern Europe, and in all probability not only their forerunner, but to a great extent their forbear. This culture itself developed out of a stage of transition from Neolithic barbarism, which we call "præ-Mycenæan," during which stone, copper, and occasionally bronze, were used side by side, pottery was rude and unpainted, and the dead were buried in cist-graves. This stage shades off on the one side (as in the first city of Troy) into the Neolithic culture, on the other (as in Cyprus) into Mycenæan civilisation, which marks the first stage of real "civilisation," properly so-called, in Europe. The earliest stages of the Mycenæan culture are known to us from discoveries of settlements with pottery, \&c., in Thêra, at Phylákopê in Melos, at Kamárais in Crete, and other isolated spots, chiefly in the Southern Ægean islands. The civilisation which we find at Mycenæ, at Vaphio, at Ialysos and elsewhere, is the same as that of Phylákopê and Kamárais, but is more highly developed in many ways. This can only be the culture of the heroic Achaians, which was overthrown by the Dorians ; its date must, then, be placed certainly before 900 B.C., even if, as is very possible, it continued to exist in Western Asia Minor and Cyprus till the eighth century. We can be more certain about its date than this; Mycenæan culture was by no means confined to

1 The Annual of the British School at Athens; No. VI. Session 1899rgoo. Pp. viii $+{ }_{156}$. With illustrations and two maps. Printed fur the subscribers and sold on their behalf by Macmillan and Co., Ltd. Price ros. $6 d$ 